\title{
Towards Modernity in Manju Kapur's A Married Woman
}

\author{
A. Sasikala \\ Research Scholar, Department of English, Yogi Vemana University, Kadapa, A.P (India)
}

\begin{abstract}
Manju Kapur speaks, with great narrative eloquence, of the idea of independence. She was awarded the Commonwealth Writers Prize for her first novel Difficult Daughters in 1999. It has earned her very substantial success, both commercially and critically, both India and in abroad. Her novel "A Married Woman" deals with new woman protagonist. It gives us revolutionary theme, the plot centers on a woman's obsession with love and lesbianism. Here, "new woman" is bold and modern in perspectives. She is job oriented, rebellious, educated and thoughtful. Kapur's heroines are mostly educated, aspiring individuals caged within the confines of a conservative society. Their education leads them to independent thinking for which their family and society become intolerant of them. They struggle between tradition and modernity. Kapur has taken profound insight into woman's inner turmoil to find a place, an identity and individuality of her own in society. For centuries, women are always back staged by patriarchal world. This paper brings out the feminist views of Manju Kapur and the issues related to the inner turmoil of women in her novel.
\end{abstract}

Keywords-Marriage, Traditional norms, Modernity, Lesbianism.

India is a developing country, it is moving ahead from tradition to modernity. The women writers line up with each other in the form of chain according to IndoAnglian literature. In this period the women have been indicating an important role to change by themselves in contributing a major segment of the Indian contemporary writing in English. It provides a reservoir of meanings and basis of discussion, insight a wealth of understanding. Most of the Indian women writers focus on the issues related to women and their predicament and they have women perspective in the world. The Indian women novelists in English try their best to deal with the women sufferings, feelings and habits apart from the other things. The women writers project the pathetic plight of forsaken women who are fated to suffer from birth to death. Due to their wide acquaintance with the nuances of life in the East and West they became aware. The women writers, who are well educated and have intellectual standards, have sharpened their surveillance of life and have imparted a psychological power to their writings. For the younger generation of Indian women novelists these writers have created a new canvas. They have predictable an insider's view of female consciousness, inner aspirations and their peculiar responses to men and things. According to Naik:

The 'new' women novelists naturally share most of preoccupations of their male counterparts, though in spite of what fanatical feminists would claim, they do 'have a room of their own' in the fictional mansion, in terms of certain pressing concerns and attitude towards them (210)

Manju Kapur is a dominant and leading woman novelist of this generation and she is a popular contemporary Indian English woman novelist. She was born in 1948 and had her education from the Miranda House University College for women and an MA at Dalhousie University in Halifax, and an M.Phil from Delhi University. At present she is an English professor in Delhi University. She has acclaimed prestigious Commonwealth Writers' Prize, in 1999 for her first book Difficult Daughters. Her books have been translated into many languages both in India and in abroad.

The novel A Married Women deals with the issues related to women. The novel is a seductive story of passion, love and attachment during the political and religious turmoil in India. The protagonist of the novel risks losing the acquisitions of her conventional marriage and bonded family by a powerful physical relationship with a much younger woman. Kapur in her novel portrays the controversial issues of homosexual relationship in a challenging way. After all lesbian and gay relationships are not mere fancies. Though we may or may not accept this it became more and more visible in this modern society.

The protagonist of the novel, Astha as a married woman becomes an enduring wife and sacrificing mother. 
She had played the role of "mother and father" for her children due to her temperamental incompatibility with her corporate thinking husband. Due to this situation she denies her self-fulfillment and breaks her marriage bond. This discontentment leads her to disobedience and agitation. Her discomfort, anxiety, loneliness and isolation do not give confidence to her to give voice to her grief over her troubled relationship, somewhat it prompts her to build up the feelings of guilt, lack of self-confidence and negativity in facing the challenges of her life. Her agitation drives to enjoy absolute loneliness, a kind of trap by the family, its commitments, its subtle domination and she craves for freedom. In the middle of the family the huge minefield of income, expenditure, knowledge, discontent, rights, responsibilities, agitation and dependency, Astha enjoys the fate of the poverty. With the growing needs of the family Astha is suffocated and "always adjusting to everybody's needs". (227) Astha knows the place of a married woman in the family that is a slave or an unpaid servant and the thought of divorce brings social and economic death in her Indian status. Astha feels herself that " $A$ willing body at night, a willing pair of hands and feet in the day and an obedient mouth", (231) are the necessary norms of a married woman. She puts marriage as a lot to enjoy bouts of rage, pain and indecisiveness so she contemplates it a terrible decision. She thinks that a married woman is an object of "mind fucking" (218) by judging the male impression of woman. She does not believe "marriage is just sex" (275) rather it provides togetherness, respect and interest. Being torn between her faith and fact, duty and responsibility, social norms and personal principles she believes "a tired woman cannot make good wives", (154) and struggles for an emotional liberty from the bane of the nation.

Manju Kapur in her second of her four novels A Married Woman (2002) frankly depicts the lesbianism and had paid less attention to the social norms in which that relationship develops. Thus the novel unfolds powerfully and explores how in a traditionalistic families in India entering the age of globalization, developing personal relations on the social norms are shaped by vast historical norms. Yet in their turn they can reform that same history in an adumbration, potentially utopian even if partial and temporary, of new and more diverse forms of human relationship. In an interview with Nivedita Mukherjee, Kapur says

It is an attempt to inject an element of artistic and emotional coherence. Actually a relationship with a woman does not threaten a marriage as much as a relationship with a man.

The portrayal of woman in Indian English fiction as the silent victim and up holder of the tradition and traditional norms of family and society in India has undergone a tremendous change and is no longer presented as a passive character. However, Manju Kapur seems aware of the fact that the women of India have indeed achieved their success in sixty years of independence. Here the novel exposes the domestic relationship. Manju Kapur has remained very truthful in portraying the women problems and the challenges they faces in their personal, religious, professional and socio-political levels. Kapur in her novel presents the changing image of women moving away from traditional norms like self-sacrificing women towards modernity that is self-assured assertive and ambitious women and also provides a medium of self-expression. Manju Kapur has sharpened her surveillance of life and has imparted a psychological power through her writings. For the younger generation of Indian women novelists she has created a new canvas.

\section{REFERENCES}

[1] Ashok Kumar, Novels of Manju Kapur: A Feministic Study New Delhi: Swarup and Publishers, 2010.

[2] Gajendra Kumar, Indian English Literature: A New Perspective New Delhi: Saarup \& Sons, 2001.

[3] Manju Kapur, A Married Woman, New Delhi: India Ink, 2002. 